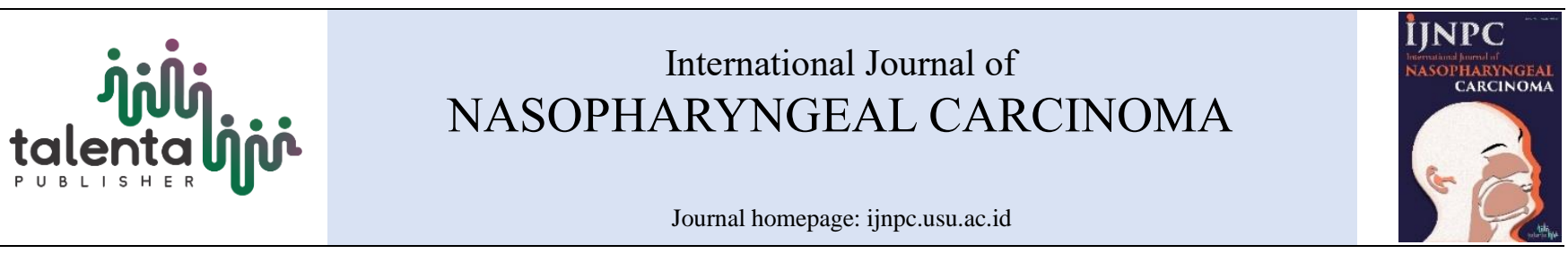

\title{
INCIDENCE OF ANEMIA IN PATIENT WITH NASOPHARYNGEAL CARCINOMAAT ENT-HNS DEPARTMENT WEST NUSA TENGGARA
}

\author{
Susilawati ${ }^{*}$, Hamsu Kadriyan ${ }^{2}$ \\ ${ }^{I}$ Department of ENT-HNS Praya Hospital West Nusa Tenggara \\ ${ }^{2}$ Department of ENT-HNS Medical Faculty Mataram University/RSUD Propinsi NTB, Indonesia
}

\begin{abstract}
Introduction: Nasopharyngeal carcinoma is common in China and Southeast Asia, including Indonesia. The cases are often diagnosed in an advanced stage with a poor prognosis.

Objective: The purpose of this study was to determine the incidence of anemia in nasopharyngeal carcinoma patients in the ENT-HNS Department West Nusa Tenggara Hospital.

Methods: the methods of this research are a descriptive study that used data from the medical record of West Nusa Tenggara Hospital. The data were obtained between April 2017 to September 2017.

Result: During the study periods, we obtained 32 cases. $75 \%$ of patients were male and $25 \%$ female, with ratio 3:1. According to the age, patients were distributed from 28 to 69 years old with peak incidence at 41-60 years old. Most patients were stage IV $(68.75 \%)$. There was $87.51 \%$ patient with anemia in this research. However,the highest number was found mild anemia $59.38 \%$ and the most types of anemia were hypochromic microcytic. Discussion: In this study, patients with advanced stages were $93.75 \%$, consist of stage IV $(68.75 \%)$ and stage III $(25 \%)$, followed by stage II $6.25 \%$, while stage I was not found. This shows that patients usually come at an advanced stage because of the low awareness of the NPC in medical personnel in Indonesia.

Conclusion: The incidence of anemia in a patient with nasopharyngeal cancer in West Nusa Tenggara Hospital is $87.51 \%$. Most of them were mild grade and hypochromic microcytic type.
\end{abstract}

\author{
Article Info \\ Keywords \\ Nasopharyngeal Carcinoma, stage, anemia
}

\section{*Corresponding author:}

Address: Jalan Basuki Rahmat No. 90 Praya Lombok Tengah

e-mail: susilawatiketut88@gmail.com

\section{INTRODUCTION}

Nasopharyngeal carcinoma (NPC) is a carcinoma that appears in the nasopharynx (the area above the throat and behind the nose), which shows the evidence that there is a mild or ultrastructural squamous differentiation microscopically [1].

In Indonesia, NPC is the 4th most malignancy after breast cancer, cervical cancer, and lung cancer. Based on GLOBOCAN 2012 [2], there were 87.000 new nasopharyngeal cancer cases occur annually (with 61.000 new cases occurring in male and 26.000 new cases in female). There were 51.000 deaths from NPC (36.000 in male, and 15.000 in female). According to global cancer statistic (GLOBOCAN) 2018, there are 129.079 new cases worldwide or $0.7 \%$ of all cancer cases with 72.987 death due to nasopharyngeal cancer annually [3].

NPC mainly found unproductive age male (the ratio of male and female is 2.18: 1) and $60 \%$ of patients were aged between 25 and 60 years [4]. The highest incidence in the world is in the province of Southeast China-with 40-50 nasopharyngeal cancer cases among 100.000 residents. On the other hand, nasopharyngeal cancer is very rare in areas of Europe and North America with an incidence $<1 / 100.000$ population [4].

The causes of malnutrition in cancer patients are very complex and multifactorial. Serotonin and bombesin hormones which are secreted by tumor cells can suppress the appetite and lead to anorexia. Nasopharyngeal cancer can also induce the inflammation of the oral mucosa, mucous membranes of the digestive tract, pain, decreased of salivary gland secretion, suppresses sensation and tooth decay. Decreased oral intake of nutrients can cause a decrease in endurance, infection and weight loss. Therapy for cancer also affects the nutritional status of patients. Maskoep (2008) on his study found that more than $40 \%$ of cancer patients who were treated were malnourished [5].

The more, unfortunately, the cases usually found in the advanced stage. This lead to the need for chemotherapy on its treatment. According to NCCN, advance nasopharyngeal cancer should be treated with a combination of radiotherapy and chemotherapy. Chemotherapy could be given in the scheme of adjuvant, neoadjuvant, concurrent or concomitantly [6]. Chemotherapy is one of the management of advanced nasopharyngeal cancer. Drugs that used in cancer therapy acting to damage, suppress and prevent the spread of cancer cells that grow rapidly. Chemotherapy drugs not only affect cancer cells but also normal cells, and in certain amounts may cause side effects on the oral and gastrointestinal mucosa, hair follicles, reproductive system, and hemopoietic system [7].

One of the effects of chemotherapy is the formation of free radicals from cisplatinadministration [5]. Excessive free radicals are toxic, which may damage normal cells in the body including bone marrow cells, which results in the suppression of the blood cell formation system. The blood cell formation system has a function to produce hemoglobin [8]

Anemia is a common problem in cancer patients who get chemotherapy because it can occur as a result of cancer or as a complication of chemotherapy administration. As many as $67-81 \%$ of patients who received chemotherapy suffer from anemia. The occurrence of anemia in anticancer administration can cause the treatment to be less effective. The response as well as the survival to radiotherapy and or chemoradiotherapy can be decreased in patients who were received radiotherapy or chemoradiotherapy [7].

Anemia is a condition where the number of red blood cells or hemoglobin in blood cells is below normal. The main factors that are causing anemia are lack of iron from food intake or low levels of iron absorption and the presence of inhibitors. It makes the absorption is not optimal and led to the lower iron body's requirement [9].

The classification of anemia based on the US National Cancer Institute, divided into 5 levels. First level (level 0) normal value, male $>12 \mathrm{~g} / \mathrm{dL}$, female $>11 \mathrm{~g} / \mathrm{dL}$. Level 1 (mild) if Hb 10.0-normal value, level 2 (moderate) if $\mathrm{Hb}$ 8.0-10.0. Level 3 (severe) if $\mathrm{Hb}$ 6.5-7.9 and the last level (extremely severe) if $\mathrm{Hb}$ less than $6.5[10,11]$.

Cancer related anemia can be a result of tumor related hemorrhage, tumor invasion of bone marrow, malnutrition caused by tumor, abnormal iron metabolism, kidney function impairment and compromised bone marrow function under the effect of various tumor-related cytokines. In most cases, the condition is a normocytic normochromic anemia with 
decreased serum iron and transferrin saturation, and normal or elevated serum ferritin. Bone marrow suppression is a common adverse reaction of chemotherapy and radiotherapy among cancer patients. The widespread use of cytotoxic drugs, particularly platinum-based agents, is an important contributing factor for tumor related anemia [12].

Based on the morphology of red blood cells, cancer can be classified as microcytic anemia (characterized by a small mean corpuscular volume (MCV) of $<80 \mathrm{fl}$ ), normocytic anemia (characterized by a normal MCV of 80-100 fl) and macrocytic anemia (characterized by a large MCV of $>100$ fl). Other morphological basis for classification may include the amount of red blood cell hemoglobin and mean corpuscular hemoglobin: hypochromic (characterized by a small mean corpuscular hemoglobin $(\mathrm{MCH})$ of $<26 \mathrm{pg}$ ) or normochromic (characterized by a normal MCH of 26-34 pg) [13].

The types of anemia divided into normochromic normocytic anemia if anemia which occurs due to excessive blood expenditure, causing the bone marrow to work harder in erythropoiesis so that many young erythrocytes are seen on the peripheral circulation. Normochromic macrocytic anemia if anemia due to vitamin B12 deficiency. Hypochromic microcytic anemia if anemia due to iron deficiency [13].

\section{MATERIAL AND METHODS}

The research was conduct with a descriptive study that used data from the medical record. The data will be taken from West Nusa Tenggara Hospital from April 2017 to September 2017. The study sample was data on patients with a diagnosis of nasopharyngeal carcinoma who treated in the ENT-HNS departement, West Nusa Tenggara Hospital. The data that will be collected including patient identity, diagnosis, the hemoglobin concentration from laboratory results and peripheral blood smear. The data then analyze descriptively.

\section{RESULT}

There were 32 patients of NPC who fulfill the study criteria, consisting of $75 \%$ of male and $25 \%$ of female (Table 1 ). According to the age category, patients were divided into several groups. Most of the patients were found in older age (41 to 60 years old)with the frequency 17 or $53.12 \%$, followed by young adults $(21-<41$ years old)with the frequency 9 or $28.13 \%$. Based on gender, in this study, the cases wsere found mostly in male (75\%) with the male and female ratio $3: 1$.

Table 1. Frequency distribution of patients with nasopharyngeal carcinoma according to age and sex

\begin{tabular}{ccccccc}
\hline $\begin{array}{c}\text { Age } \\
\text { (year) }\end{array}$ & \multicolumn{2}{c}{ Male } & \multicolumn{2}{c}{ Female } & \multicolumn{2}{c}{ Total } \\
\hline$<21$ & frequency & $\mathbf{\%}$ & frequency & $\boldsymbol{\%}$ & frequency & $\mathbf{\%}$ \\
$21-<41$ & - & - & - & - & - & - \\
$41-60$ & 7 & 21.87 & 2 & 6.25 & 9 & 28.13 \\
$>60$ & 12 & 37.50 & 5 & 15.62 & 17 & 53.12 \\
\hline Total & 5 & 15.63 & 1 & 3.13 & 6 & 18.75 \\
\hline
\end{tabular}

Table 2. Distribution of patients with nasopharyngeal carcinoma based on the stage

\begin{tabular}{lcc}
\hline \multirow{2}{*}{ Stadium } & $\begin{array}{c}\text { Frequency } \\
\text { f }\end{array}$ & $\begin{array}{c}\text { Percentage } \\
\mathbf{\%}\end{array}$ \\
\hline I & - & - \\
II & 2 & 6.25 \\
III & 8 & 25.00 \\
IV A & 10 & 31.25 \\
IV B & 12 & 37.50 \\
IV C & - & - \\
\hline Total & $\mathbf{3 2}$ & $\mathbf{1 0 0}$ \\
\hline
\end{tabular}

In table 2, patients generally come at an advanced stage; most of them are stage IV ( $68.75 \%)$. This case is followed by patients with stage III and II were found $25 \%$ and $6.25 \%$ consecutively.

Table 3. Distribution of patients with nasopharyngeal carcinoma according to anaemic status (US NCI)

\begin{tabular}{lrrrrrr}
\hline \multicolumn{1}{c}{ Anemia } & \multicolumn{2}{c}{ Male } & \multicolumn{2}{c}{ Female } & \multicolumn{2}{c}{ Total } \\
\cline { 2 - 8 } & \multicolumn{1}{c}{ f } & \multicolumn{1}{c}{$\%$} & \multicolumn{1}{c}{ f } & \multicolumn{1}{c}{$\%$} & \multicolumn{1}{c}{ f } & \multicolumn{1}{c}{} \\
\hline Normal & 4 & 12.50 & - & - & 4 & 12.50 \\
Mild & 16 & 50.00 & 3 & 9.38 & 19 & 59.38 \\
Moderate & 4 & 12.50 & 4 & 12.50 & 8 & 25.00 \\
Severe & - & - & 1 & 3.13 & 1 & 3.13 \\
extremely severe & - & - & - & - & - & - \\
\hline Total & $\mathbf{2 4}$ & $\mathbf{7 5}$ & $\mathbf{8}$ & $\mathbf{2 5}$ & $\mathbf{3 2}$ & $\mathbf{1 0 0}$ \\
\hline
\end{tabular}

In the table above, patients with normal $\mathrm{Hb}$ was found in $4(12.50 \%)$ patients, on the other hand, the most patients categorized as mild anemia with the frequency $19(59.38 \%)$. In this study, we also found the cases with severe anemia $1(3.13 \%)$ patients, but very severe anemia was not found.

Table 4. Distribution of $\mathrm{Hb}$ levels before and after chemotherapy

\begin{tabular}{lrrrr}
\hline \multirow{2}{*}{ Anemia } & \multicolumn{2}{c}{ Before Chemotherapy } & \multicolumn{2}{c}{ After Chemotherapy } \\
\cline { 2 - 5 } & \multicolumn{1}{c}{ f } & \multicolumn{1}{c}{ f } & \multicolumn{1}{c}{ f } & \multicolumn{1}{c}{} \\
\hline Normal & 4 & 12.5 & 4 & 12.5 \\
Mild & 19 & 59.375 & 27 & 84.375 \\
Moderate & 8 & 25 & 1 & 3.125 \\
Severe & 1 & 3.125 & 0 & 3.125 \\
extremely severe & - & - & - & - \\
\hline Total & $\mathbf{3 2}$ & $\mathbf{1 0 0}$ & $\mathbf{3 2}$ & $\mathbf{1 0 0}$ \\
\hline
\end{tabular}

In this study also analyzed the $\mathrm{Hb}$ level before and after chemotherapy. According to table 4, most patients before and after chemotherapy suffered from mild anemia. However, there is not a significant difference between both groups.

Table 5. Distribution of types of anemia based on the complete blood test result and peripheral blood smear

\begin{tabular}{|c|c|c|c|c|c|c|}
\hline \multirow[t]{2}{*}{ Anemia } & \multicolumn{2}{|c|}{ Mild } & \multicolumn{2}{|c|}{ Moderate } & \multicolumn{2}{|c|}{ Severe } \\
\hline & f & $\%$ & f & $\%$ & f & $\%$ \\
\hline $\begin{array}{l}\text { Normositik } \\
\text { Normokromik }\end{array}$ & - & - & 1 & 3.13 & - & - \\
\hline $\begin{array}{l}\text { Makrositik } \\
\text { Normokromik }\end{array}$ & - & - & - & - & - & - \\
\hline $\begin{array}{l}\text { Mikrositik } \\
\text { Hipokromik }\end{array}$ & 9 & 28.13 & 2 & 6.25 & - & - \\
\hline
\end{tabular}

We only found the data on 12 patients. In table 5 , according to complete blood test result most of the types of anemia was hypochromic microcytic $11(34.38 \%)$ and according to peripheral blood smear only1 (3.13\%) patients with anemia normocytic normochromic.

\section{DISCUSSION}

According to the results of our study, we found a comparison of male and female was 3: 1. Yenita et al. (2010) on their research in West Sumatra gets a ratio $2: 1$ [14]. The research in the United States has found a ratio of 2:1 [2]. NPC is always found higher in the male. The incidence of NPC often occurs with male and female ratios 3:1 [15]. It has not been found with certainty the cause of high male sufferers than female in this cancer. Male may be more likely to be exposed to carcinogens in their work environment than female so that they are more at risk for cancer. In this study obtained the highest age range between 41-60 years old, this result is similar to some literature whom $60 \%$ of patients distributed in the age group between 25 to 60 years old.

In this study, patients with advanced stages were $93.75 \%$, consist of stage IV $(68.75 \%)$ and stage III $(25 \%)$, followed by stage II $6.25 \%$, while stage I was not found. This shows that patients usually come at an advanced stage because of the low awareness of the NPC in medical personnel in Indonesia. The hidden location of the tumor in the nasopharynx may lead to the requirements of a special examination in a hospital that has complete facilities. Those factors also make the early detection of this cancer becoming more complicates. Knowledge of the signs and symptoms that often arise such as nasal obstruction, epistaxis, headaches, and tinnitus is often considered a common cold that makes nasopharyngeal cancer detection is lately. The delay in diagnosis is also related to the patient's unconsciousness to NPC as well as the tendency of patients to seek traditional medicine as the first treatment [16].

In cases of malignancy anemia often occurs. In this study, mild anemia was found which could mostly occur as a result of cancer or as a complication of giving chemotherapy administration. The main factors causing anemia are lack of iron consumption from food or low levels of iron absorption as well as the presence of absorption inhibitors so that it cannot be absorbed optimally and does not meet the body's requirments [9].

In this study, the patients before and after chemotherapy mostly had mild anemia. It happens from the beginning of the patients' diagnosis as NPC. It may be due to lack of nutrition and because of cancer progress. The chemotherapy did not affect the decrease in $\mathrm{Hb}$ according to our data. This may be because they were threatened to improve their general condition and some of them receive the blood transfusion to gain the Hb level [17].

In this study, most types of anemia are hypochromic microcytic. It means that the number of red blood cells or hemoglobin (an oxygen transport protein) in blood cells was below the normal limit and this may be caused by iron deficiency. Other causes of iron deficiency are insufficient 
of iron intake, impaired absorption, persistent blood loss as in gastrointestinal bleeding, and neoplasms. Anemia due to iron deficiency occurs gradually, starting from the iron loss over the intake, reduced iron reserves which can not meet the requirements for the red blood cells production, then anemia begins. Then bone marrow tries to replace iron deficiency by speeding up cell division and producing red blood cells in very small size (microcytes). With the worsening of iron deficiency and anemia, symptoms will arise such as fatigue, shortness of breath, and lack of energy.

\section{CONCLUSION}

The incidence of anemia in a patient with nasopharyngeal cancer in West Nusa Tenggara Hospital is $87.51 \%$. Most of them were mild grade and hypochromic microcytic type.

\section{REFERENCE}

[1] Chan J, Pilch B, Kuo T, Wenig B, Lee A. Tumours of the nasopharynx Pathology \& Genetics head and Neck tumors Lyon. 2005:81-106.

[2] Ferlay J, Soerjomataram I, Dikshit R, Eser S, Mathers C, Rebelo M, et al. Cancer incidence and mortality worldwide: sources, methods and major patterns in GLOBOCAN 2012. International journal of cancer. 2015;136(5):E359-E86.

[3] Bray F, Ferlay J, Soerjomataram I, Siegel RL, Torre LA, Jemal AJCacjfc. Global cancer statistics 2018: GLOBOCAN estimates of incidence and mortality worldwide for 36 cancers in 185 countries. 2018;68(6):394-424

[4] Chang ET, Adami H-O. The enigmatic epidemiology of nasopharyngeal carcinoma. Cancer Epidemiology and Prevention Biomarkers. 2006;15(10):1765-77.

[5] Maskoep W. Terapi Nutrisi Pada Penderita Kanker. Pusat Pengembangan Paliatif dan Bebas Nyeri RSU dr Soetomo-FK UNAIR Surabaya. 2008.

[6] Colevas AD, Yom SS, Pfister DG, Spencer S, Adelstein D, Adkins D, et al. NCCN guidelines insights: head and neck cancers, version 1.2018. 2018;16(5):479-90.

[7] Aziz M, Andrijono SA. 2010. Buku Acuan Nasional Onkologi Ginekologi Edisi kedua Jakarta: Yayasan Bina Pustaka Sarwono Prawirohardjo. 2015.

[8] Aminullah Y. Wiranto., Susilaningsih, N. 2012, Pengaruh Kombinasi Vitamin C dan E Dosis Tinggi terhadap Sistem Hemopoetik Penderita Kanker Kepala dan Leher yang Mendapat Kemoterapi Cisplatin. Jurnal Medica Hospitalia vol 1 (2): 89.94.

[9] Zarianis Z. Efek Suplementasi Besi-Vitamin C Dan Vitamin C Terhadap Kadar Hemoglobin Anak Sekolah Dasar Yang Anemia Di Kecamatan Sayung Kabupaten Demak The Effect Of Iron-Vitamin C And Vitamin C Supplementation On Hemoglobin Level Of Anemic Elementary School Children At Sayung Subdistrict Demak District: Program Pascasarjana Universitas Diponegoro; 2006.

[10] Zhang Z, SHEN T. The diagnosis and curative standard of Hematopathy. Beijing: Science Publishing House; 2007.

[11] Groopman JE, Itri LMJJotNCI. Chemotherapy-induced anemia in adults: incidence and treatment. 1999;91(19):1616-34.

[12] Del Mastro L, Gennari A, Donati SJAoo. Chemotherapy of non-smallcell lung cancer: role of erythropoietin in the management of anemia. 1999;10(suppl 5):S91-S4.

[13] Birgegård G, Aapro MS, Bokemeyer C, Dicato M, Drings P, Hornedo $\mathrm{J}$, et al. Cancer-related anemia: pathogenesis, prevalence and treatment. Oncology. 2005;68(Suppl. 1):3-11.

[14] Yenita AA. Studi retrospektif karsinoma nasofaring di Sumatera Barat: reevaluasi subtipe histopatologi berdasarkan klasifikasi WHO. Padang: Fakultas Kedokteran, Universitas Andalas. 2010.

[15] Adham M, Kurniawan AN, Muhtadi AI, Roezin A, Hermani B, Gondhowiardjo S, et al. Nasopharyngeal carcinoma in Indonesia: epidemiology, incidence, signs, and symptoms at presentation. Chinese journal of cancer. 2012;31(4):185.

[16] Khoo AS-B, Pua K-C. Diagnosis and clinical evaluation of nasopharyngeal carcinoma. Nasopharyngeal Carcinoma: Springer; 2013. p. 1-9.

[17] ZW W, FC L. Epidemiology study of four results of pre-transfusion test in 2286 patients. ZhiYe Yu Jian Kang. 2004:20; 63-5 